\begin{tabular}{|c|c|}
\hline MAGNA & Literature Reviews \\
MEDIKA & Berkala Ilmiah Kedokteran dan Kesehatan \\
\cline { 2 - 4 } & Journal Page: https://jurnal.unimus.ac.id/index.php/APKKM \\
\hline
\end{tabular}

\title{
The Effect of Shalat Movement on Cardiorespiratory Fitness in The Elderly
}

\author{
Zakiyah Darajat Munthe ${ }^{1}$, Elman Boy ${ }^{2}$, Al Furqon ${ }^{3}$ \\ 1) Medical Faculty of Universitas Muhammadiyah Sumatera Utara \\ 2) Public Health Depart of Medical Faculty of Universitas Muhammadiyah Sumatera Utara \\ 3) Tilburg University, Netherlands
}

\begin{tabular}{l}
\hline \multicolumn{1}{c}{ Article Info } \\
\hline Article history: \\
Received 05 December 2020 \\
Revised 09 July 2021 \\
Accepted 12 July 2021 \\
Available online 01 August 2021 \\
\hline Keywords: \\
Elderly, Prayer Movement, Car- \\
diorespiratory Fitness \\
\hline Correspondence: \\
elmanboy@umsu.ac.id \\
\hline
\end{tabular}

How to cite this article:

Zakiyah Darajat Munthe, Elman Boy, Al Furqon. The Effect of Shalat Movement on Cardiorespiratory Fitness in The Elderly. MAGNA MEDIKA Berk Ilm Kedokt dan Kesehat. 2020;8(2):84-92

\begin{abstract}
Background: An elderly is a stage of human development after adulthood and the last human life cycle. As a person gets older, the disability increases in daily life activities as a result of decreasing physical levels. The aging process shows physiological, cognitive, and psychological changes in the human body. Decreased components of fitness, such as muscle strength, balance, and the cardiorespiratory system, affect the development of disabilities. Therefore, in Islam, there is prayer service, which can be an effort to improve the cardiorespiratory fitness of the elderly. Wherewith prayer can become a sports medium that is both physical and spiritual.
\end{abstract}

Aims: To determine the effect of Shalat movement on cardiorespiratory fitness in the elderly

Method: This type of literature study is a literature review. The method used in writing this article is English studies relevant to the topic was carried out using the PubMed, Google Scholar, and Semantic Scholar databases, restricted from 2010 to 2020 . The keywords used in the article search were elderly, prayer movement, and cardiorespiratory fitness. Results of the study: The effect of prayer movement on cardiorespiratory fitness is that it can improve blood circulation from the heart to the rest of the body, increase blood flow to the brain and increase lung elasticity.

Conclusion: There is a significant effect of prayer movement on the increase in cardio respiration of the elderly. 


\section{INTRODUCTION}

Globally, the World Health Organization (WHO) estimates that by 2050 , the population aged 60 years or older will double, while those aged 80 years or older will number 400 million people. ${ }^{1}$ Aging is a process that cannot be avoided; usually, it is said that the elderly are measured by age. ${ }^{2}$ In the process itself, physical, mental, psychosocial, and spiritual changes tend to decline. However, the aging process is not the same as each other because there are differences in genetics, lifestyle, and overall health. ${ }^{3}$

The higher the life expectancy of the elderly, the higher the risk factors for various health problems. Physical changes in the elderly can be a condition for the elderly to suffer from diseases such as cardiovascular changes, namely decreased elasticity of blood vessels, changes in respiration, namely the strength of the respiratory muscles, and changes in hearing and vision. ${ }^{4}$

The cardiorespiratory system consists of the heart and lungs, which are the organs for human respiration. Cardio respiration function is the ability of the heart, lungs, and blood vessels to function optimally at rest and work in taking oxygen and channeling it to active tissues so that it can be used in the body's metabolic process. Cardiorespiratory fitness is said to be healthy if, during physical exercise, you do not experience shortness of breath. Fitness can be measured by using oxygen maximally per minute during activity or exercise. ${ }^{5}$

One of the factors that can slow down the development of premature aging is physical exercise. When carried out regularly, an activity can improve and maintain body health, physical abilities and improve functions of daily life. ${ }^{6,7}$ Physical activity is a protective factor for noncommunicable diseases such as heart disease, diabetes, cancer, stroke, and quality of life. ${ }^{8,9}$ In addition, it can also increase bone density, reduce fat accumulation, increase body mass index and reduce the risk of damage to the musculoskeletal system. ${ }^{6}$

In Islam, Shalat (prayer) is an obligatory activity for Muslims. Repetition of how many body movements carried out in Shalat is equivalent to sports movements that the body needs to achieve excellent health. The movements carried out in the implementation of Shalat as exemplified by the Prophet S.A.W, seen from various scientific disciplines such as medicine, biology, and physics, bring innumerable benefits. ${ }^{10}$

\section{LITERATURE REVIEW}

\section{Old Age/Elderly}

An older person has a chronological age of 65 years and above, whereby the age of 65 to 74 years is considered a young or early elderly and aged 75 years and above as late elderly. Old age is a normal developmental stage for every individual and is a reality that cannot be avoided ${ }^{2}$.

Indonesia is currently changing in terms of the demographic characteristics of the population. There has been an increase in the number of older people. Based on 2009 data, Indonesia's elderly population reached $8.37 \%$ of the total population or an estimated 19,318,029 people ${ }^{11}$. The United Nations projects that this number will continue to rise, reaching 25.5 million people by 2020 . This rapid increase in the elderly population is the impact of an increase in life expectancy. This, in return, impact the number and percentage of the elderly population. ${ }^{12,13}$ 
Aging is associated with a decrease in physical functions that affect critical vital processes that impact a person's independence, social participation, and quality of life. Increasing in age, a person will become elderly and experience an increased disability in daily activities due to decreasing physical strength and fitness. The aging process shows physiological changes in the human body. Decreased fitness components such as muscle strength, balance, and the cardiorespiratory system predispose to the development of disability. $^{14}$

Physiologically, an older person undergoes various changes in his body to achieve a homeostatic condition. This includes a decrease in physiological reserves and an increase in the need for existing physiological reserves to maintain homeostasis. However, this does not necessarily make an older person helpless and unable to carry out everyday activities. Various variations between individuals affect the physical capacity of the elderly. An elderly still can continue to carry out activities of daily living as well as possible, even as well as young individuals. ${ }^{15}$

\section{Elderly Cardiorespiratory Fitness}

Cardiorespiratory fitness is the ability of the heart, lungs, and blood vessels to take in oxygen and distribute it to the tissues while at rest or during exercise. Cardiorespiratory fitness can be measured by using maximal oxygen per minute while exercising at the maximum level. Cardiorespiratory fitness is said to be healthy if, during physical exercise, you do not experience shortness of breath. ${ }^{5}$
The decline in fitness in the elderly is due to several factors such as the biological aging process, lifestyle changes, development of chronic diseases, drugs, or a combination of these reasons. The typical changes due to the aging process are; an increase in maximal heart rate, maximum cardiac output, decreased body mass, increased fat mass, and changes in oxidative muscle capacity. ${ }^{16}$

In old age, a person has a higher risk of experiencing health problems than a person at a young age. From the results of data analysis, it was found that age is a factor in the risk of hypertension. This is in line with the results of Zamhir Setiawan's study, which found that at the age of 25-44 years, the prevalence of hypertension was $29 \%$. At the age of $45-64 \%$ years was $51 \%$, and at aged $>65$ years was $65 \%$. In Hasurungan's study, compared to 55-59 years, at the age of 6064 years, there was an increase in the risk of hypertension by 2.18 times, aged 65-69 years by 2.45 and age $>70$ years by 2.97 times. ${ }^{17,18}$

Cardiorespiratory fitness is a protective factor against the cardiovascular risks associated with obesity. Increased adiposity, particularly visceral adiposity, is associated with decreased vascular endothelial function. Endothelial function refers to the general functional capacity of vascular endothelial cells, namely to synthesize and release nitric oxide (NO). The synthesis and/or availability of nitric oxide is associated with increased vascular permeability, inflammation, adhesion, thrombosis, reduced vasodilatory capacity, and impaired endothelial function associated with several cardiovascular risk factors. ${ }^{19}$

Cardiovascular changes in the elderly; 


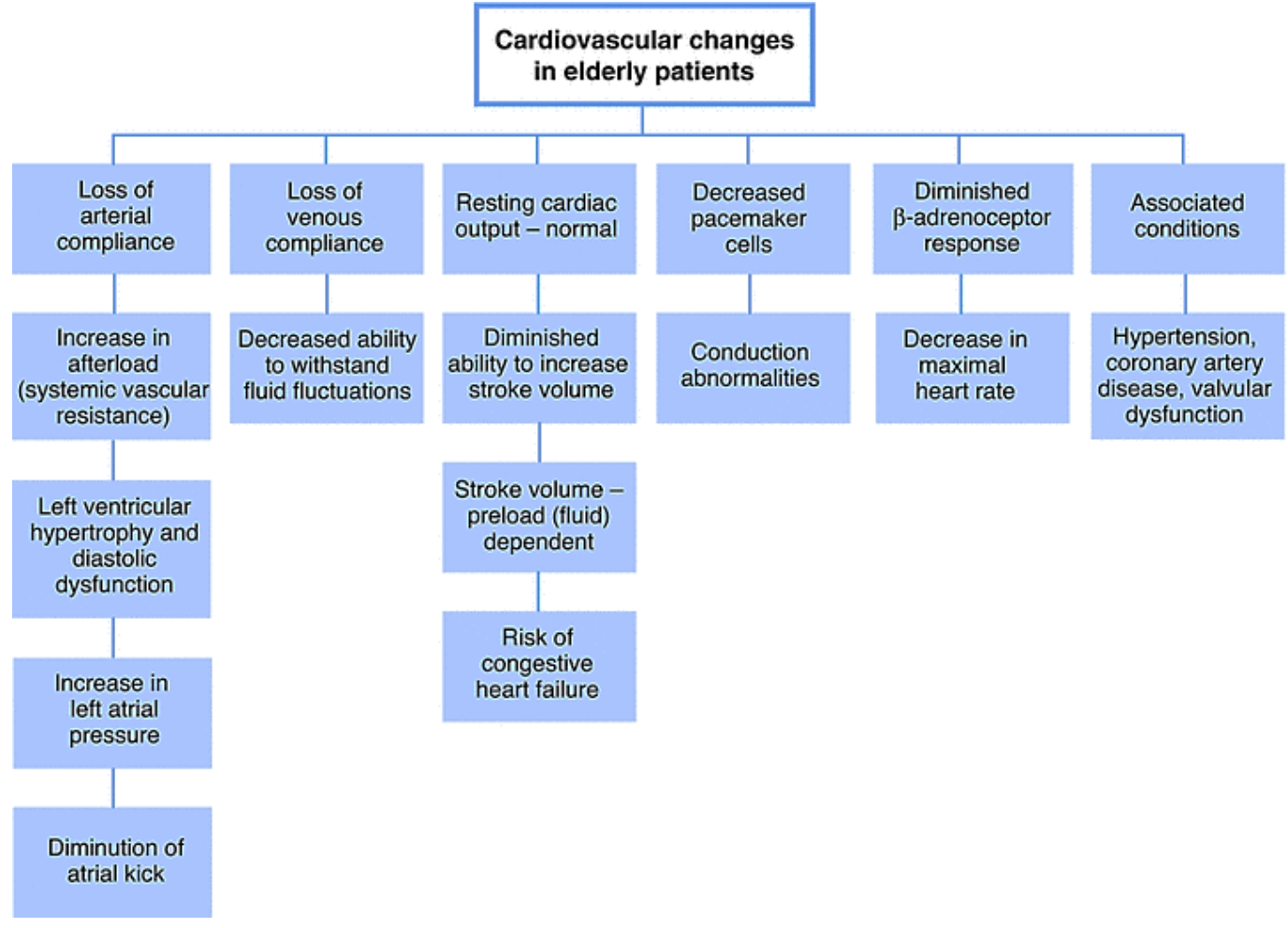

Picture 1. Changes in the cardiovascular system in the elderly. ${ }^{20}$

\section{YOUNG}

A

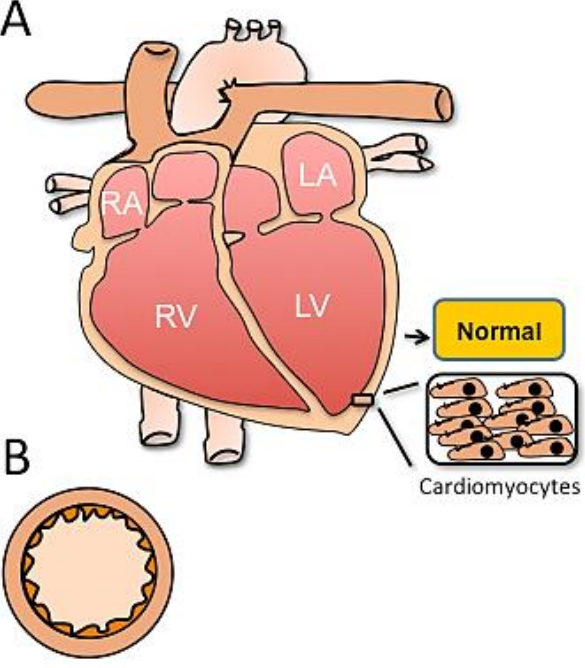

\section{AGED}

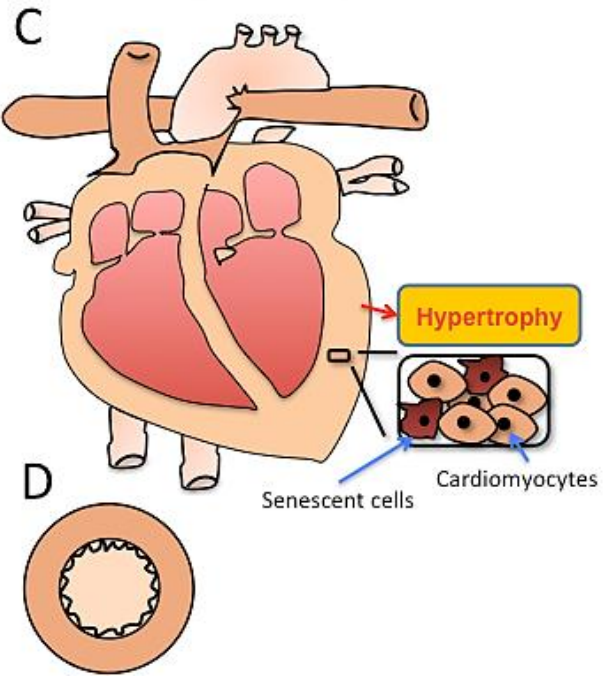

Picture 2. Changes in th heart and vascular system are associated with age. The heart (before old age) has typically highly functional cardiomyocytes, atria, and ventricles (A). Arteries (before old age) have a normal lumen, average arterial thickness, and efficient contractile and relaxing properties (B). However, the aging heart experiences an increase in thickness in the heart muscle due to hypertrophy. In particular, cardiomyocytes from the aged heart show concomitant hyperplasia with some aging cardiomyocytes (C). Aging arteries also have increased thickness, reduced lumen, and less efficient contractile and relaxing properties (D). These age-related changes ultimately lead to a decrease in the function of the heart and blood vessels in the elderly. ${ }^{21}$ 
Changes can be observed not only from the structural and functional aspects of the heart but also from the molecular point of view. It also changes, as shown in the following diagram:
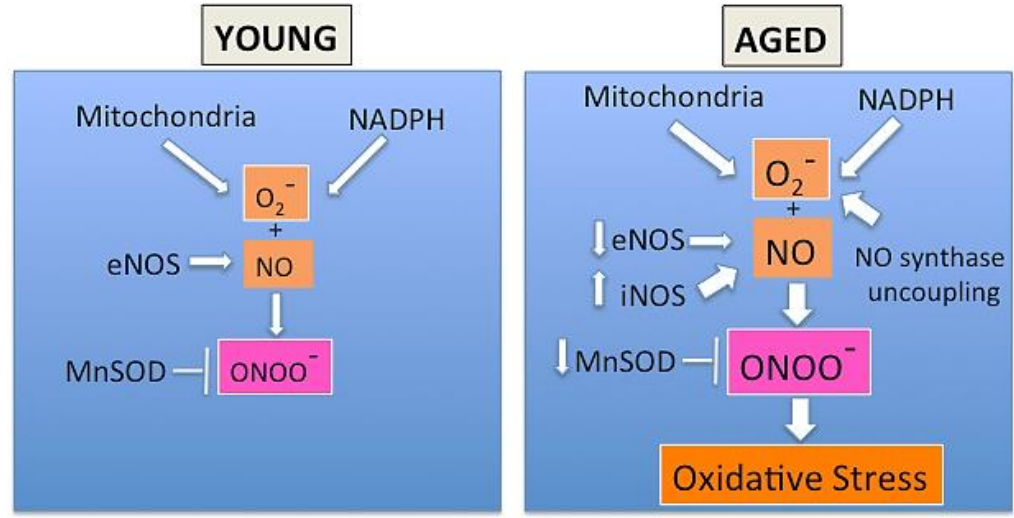

Picture 3. Oxidative stress in aging endothelial cells compared to endothelial cells that (before aging). Aging endothelial cells produce increased levels of free radicals. In the presence of Nitric Oxide (NO), which is derived from iNOS in aging endothelial cells, O2- causes the formation of a potent free radical known as Peroxynitrite (ONOO-). These changes lead to increased oxidative stress that damages macromolecules and ultimately lead to loss of endothelial cell function in senescent cells. ${ }^{21}$

Cardiorespiratory changes in the elderly are:

- Increase thickening of the walls and constriction of blood vessels.

- Endothelial dysfunction

- Myocyte hypertrophy and degeneration

- Connective tissue changes due to increased interstitial collagen

- Amyloid formation of the heart

- Fat tissue disposition

- Increase in maximal heart rate

- Increase in maximal stroke volume

- Increase in maximal cardiac output

- Decrease in body mass

- Changes in the oxidative capacity of muscles

- Decrease in lung elasticity

\section{Shalat (prayer) movements on Cardiorespira- tory Fitness}

Shalat means prayer. According to the Indonesian language, Shalat is an act of worship to Allah S.W.T that Muslims must perform. Shalat begins with the Takbir and ends with Salam and is equipped with certain conditions, pillars, movements, and recitations..$^{22}$ Movements in Shalat that have been exemplified by the Prophet Rasulullah S.A.W contains many benefits. The movements in Shalat as exemplified by the Prophet Rasulullah S.A.W have many benefits for the body health; both in terms of medicine, biology, chemistry, physics, and so on. ${ }^{23}$

According to Ibnu Qayyim, a balanced exercise produces reddened skin that feels hot and has a moist body condition. If you exercise until you sweat profusely, it is an act that exceeds the limit. Limbs will be strengthened according to the type of sports performed. Ibnu Qayyim also said the benefits of movements in an exercise are the essential factor in making the body light and energetic, creating appetite, strengthening joints, and strengthening body tissues to prevent the body from physical and psychological diseases. ${ }^{24}$

In Subekti's study in 2014, it was found that there was a relationship between physical activity 
and blood pressure in the elderly in Sumberan Sumberagung Moyudan Sleman, Yogyakarta. From the study results, it was found that physical activity can lower blood pressure because it can calm the sympathetic nervous system, which slows down the heart rate.

Shalat affects reducing blood pressure in hypertensive patients. The solemnity of Shalat has a significant effect on systolic and diastolic blood pressure. This is because solemnity is an aspect that is in line with the concept of meditation and relaxation, which is a non-pharmacological therapy in reducing blood pressure in hypertensive patients.

The effects of Shalat on the body's circulatory system are: ${ }^{23}$

- Ensure the fulfillment of nutrient needs and the immediate disposal of the body's metabolic wastes

- Plays an essential role in the distribution of body heat

- Transports oxygen from the lungs to all tissues

- Transports carbon dioxide from all tissues to the lungs.

- Transports hormones from endocrine glands to target organs.

- Increase lungs elasticity.

The following are the benefits of movements in Shalat: $27,28,29,30,31,32,33,34,35$

a. Takbiratul Ihram (raising of hands and reciting "Allahu Akbar")

This movement helps smooth the flow of blood and lymph and improves muscle strength in the arm. When lifting both hands and arms, the shoulder muscles stretched so that the flow of oxygenrich blood becomes smooth. Then, both hands are clasped in front of the stom- ach or lower chest. These movements are similar to movements during exercise, it trains and moves muscles and joints so that they are not stiff and prevents pain around the joints and shoulders, especially in the upper body.

b. Rukuk (belt-low bowing)

This movement helps to maintain the perfect position and function of the spine (corpus vertebrae) as the support for the body and nerve system. This position promotes the relaxation of the spine to the waist to be free from pain or concerns around the spine and waist. The hands resting on the knees help relax the shoulder muscles and facilitate blood flow in the neck and arm areas. In addition, Rukuk (belt-low bowing) is a urinary exercise to prevent prostate disorders.

c. Sujud (kneeling while laying the forehead to the floor in prayer)

This position helps to stimulate and increase blood flow to the brain so that the brain functions better. The lymph flow is pumped to the neck and armpits. The position of the heart above the brain causes oxygen-rich blood to flow maximally to the brain.

\section{CONCLUSION}

Indonesia is currently changing in terms of the demographic characteristics of the population. There has been an increase in the number of older people. The birth rate is relatively declining over time, and the elderly population is overgrowing. In terms of health, the aging process in 
the elderly is one of the risk factors for genetic changes based on current disease conditions and environmental factors.

The movements in Shalat are very beneficial in contributing to a person's health, both physically and mentally. This is not only from a medical point of view but also as a spiritual medium or path to Allah S.W.T.

As an obligatory act of worship in Islam, the performing of Shalat is seen as a symbol and ritual and as a practice in which there are many lessons to be learned related to faith and medicine. According to Islam, Shalat has positive implications for one's health and life. Shalat prevents a person from indecency and evil.

Likewise, with the medical implications of Shalat seen through the physical movements, from the beginning of Shalat, namely taking ablution, where one must be cleansed. Even in the performing of Shalat itself, from Takbir, Rukuk, Sujud to Salam. These are a physical activity that requires our body to move. Shalat benefits a person medically, psychologically, and spiritually.

The movements can be replicated outside Shalat and transformed into an exercise regime for the elderly. Many can enjoy the benefits of the movements towards better health, muslims and non-muslims. There is a significant effect of Shalat movement on the increase in cardio respiration of the elderly.

\section{REFERENCE}

1. WHO. (2012). 10 Facts On Ageing And The Life Course. http://www.who.int/features/factfiles/agei ng/ageing facts/en/index.html (accessed 03/12/20).
2. Orimo, H., Ito, H., Suzuki, T., Araki, A., Hosoi, T., \& Sawabe, M. (2006). Reviewing the Definition of "Elderly." Geriatrics \& Gerontology International. Vol;6(3). (pp.149-158). DOI: $\quad$ 10.1111/j.14470594.2006.00341.x

3. Levine, ME. (2013). Modeling the Rate of Senescence: Can Estimated Biological Age Predict Mortality More Accurately Than Chronological Age. J Gerontol A Biol Sci Med Sci. Vol: 68(6). (pp.667-674). DOI: 10.1093/gerona/gls233

4. Homeier, D. (2014). Aging Physiology, Disease, and Abuse. Clin Geriatr Med. Vol. 30. (pp. 671-80)

5. Hakola, L. (2015). Cardiorespiratory Fitness and Physical Activity in Older Adults. Kuopio Research Institute of Exercise Medicine. Vol. 276. (pp.1-91)

6. Andrieiva, O. et al., (2019). Effects of Physical Activit on Aging Process in Elderly Person. Journal of Physical Education and Sport.

7. Persson, A., \& While, A. (2011). Physical Activity Among Older People and Related Factors. Health Education Journal.

8. Livingston, G., Sommerlad, A., Orgeta V., et al. (2017). Dementia Prevention, Intervention And Care. The Lancet.

9. Das, P., \& Horton, D. (2012). Rethinking Our Approach to Physical Activity. The Lancet.

10. Sagiran. (2014). Mukjizat Gerakan Salat, (Penelitian Dokter Ahli Bedah dalam Pencegahan \& Penyembuhan Penyakit). Jakarta: Qultum Media.

11. Komisi Nasional Lanjut Usia. Profil 
penduduk lanjut usia 2009. (2009). Jakarta: Kementerian Sosial Republik Indonesia. (pp.28).

12. Soejono, CH,. (2009). Pengkajian Paripurna pada Pasien Geriatrik. Buku Ajar Ilmu Penyakit Dalam. Ed 5. Jakarta: Interna Publishing. (pp.1425).

13. Badan Pusat Statistik. (2019). Statistika Penduduk Lanjut Usia. Jakarta: BPS.

14. Mason R., et.al. (2016). The Effects of Exercise on the Physical Fitness of High and Moderate-Low Functioning Older Adult Women. Journal of Aging Research. Vol.10. (pp.1-7)

15. Setiati S., dkk. (2009). Proses Menua dan Implikasi Kliniknya. Buku ajar Ilmu Penyakit Dalam. Ed 5. Jakarta: Interna Publishing. (pp. 1346-7)

16. Villareal C., dkk. (2014). Effect of Exercise on Cardiovascular Performance in the Elderly. Frontiers in Physiology. 5(51). (pp. 1-8).

17. Nuryaningsih, S., dkk. (2020). Pengaruh Gerakan Shalat terhadap Perubahan Status Hemodinamika Lansia dengan Hipertensi di Puskesmas Plupuh II Sragen.

18. Andria, KM. (2013). Hubungan antara Perilaku Olahraga, Stres dan Pola Makan dengan Tingkat Hipertensi pada Lanjut Usia di Posyandu Lansia Kelurahan Gebang Putih Kecamatan Sukolilo Kota Surabaya. Jurnal Promkes. Vol:1(2). (pp. 111-7)

19. Davidson, K., et al., (2014). Relationships Between Obesity, Cardiorespiratory Fitness, and Cardiovascular Function. Journal of Obesity. Vol.1. (pp.1-9)
20. Bose, R., \& Barnett, S. (2011). The Elderly Patient. Essential Clinical Anesthesia (pp. 7076). Cambridge: Cambridge University Press.

doi:10.1017/CBO9780511842306.013

21. Shavali, Wang, Z., Inuzuka, H., Liu, P., \& Wei, W. (2012). Endothelium Aging and Vascular Diseases, Senescence and Senescence-Related Disorders. IntechOpen, DOI: 10.5772/53065. Available from https://www.intechopen.com/books/senes cence-and-senescence-relateddisorders/endothelium-aging-and-vasculardiseases

22. Ahmad, N. (2009). Panduan Praktis dan Lengkap Shalat. Jakarta.

23. Elimartati. (2016). Tinjauan dari berbagai Aspek tentang Rahasia Pelaksanaan Salat (Studi Hukum Islam, Biologi dan Fisika). Batusangkar International Conference I.

24. Setiawan, GW. (2013). Pengaruh Senam Bugar Lanjut Usia (Lansia) Terhadap Kualitas Hidup Penderita Hipertensi. Jurnal Biomedik, Vol:1(2).

25. Tedjasukmana, P. Tata Laksana Hipertensi. (2013). Departemen Kardiologi, RS Premier Jatinegara dan RS Graha Kedoya, Jakarta, Indonesia.

26. Widyastuti, IW. (2015). Pengaruh Terapi Murottal Surah Ar-Rahman terhadap Perubahan Tekanan Darah pada Lanjut Usia (Lansia) Penderita Hipertensi di Posyandu Lansia Kenanga Wilayah Kerja UPK Puskesmas Siantan Hulu Kecamatan Pontianan Utara. ProNers. Vol. 3(1).

27. Khoiriyati, A., Huriah, T. (2019). Efektivitas 
Pemberian Intervensi Gerakan Salat terhadap Penurunan Tekanan Darah pada Lansia. J Keperawatan. Vol.12(1). (pp.112)

28. Noorbhai, MH. (2013). The Utilization and Benefits of Salaah (Muslim Prayer) As A Means of Functional Rehabilitation and Low-Intensity Physical Activity. The Experiment International Journal of Science and Technology. Vol.7(3). (pp: 401-3)

29. Suparman, D. (2015). Pembelajaran Ibadah Shalat dalam Perspektif Psikis dan Medis. $\operatorname{Vol}(9: 2)$.

30. Ikhsan, M., \& Boy, E. (2020). Cardiovascular Changes Among Healthy Elderly. Magna Medika (pp. 70-82). DOI: https://doi.org/10.26714/magnamed.7.2.2 020.70-82

31. Siagian, FD., \& Boy, E. (2019). Pengaruh Grakan Shalat dan Faktor Lain Terhadap Kebugaran Jantung dan Paru pada Lansia. Magna Medika. Vol. 6, No.2 (pp. 107-12). DOI: 10.26714/magnamed.6.2.2019.107-

112

32. Larasati, AN., \& Boy, E. (2019). The Impact of Physical Activity in Elderly. Magna Medika. Vol. 6, No.2 (pp. 113-121). DOI: 10.26714/magnamed.6.2.2019.107-

112

33. Dharma, US., \& Boy, E. (2019). Peranan Latihan Aerobik dan Gerakan Shalat Terhadap Kebugaran Jantung dan Paru Lansia. Magna Medika. Vol. 6, No.2 (pp. 122-9). DOI: 10.26714/magnamed.6.2.2019.122129

34. Fikri, M., \& Boy, E. (2019). Pengaruh Gerakan Sholat Terhadap Tekanan Darah pada Lansia. Magna Medika. Vol. 6, No.2 (pp. 130-7).

DOI: 10.26714/magnamed.6.2.2019.107-

112

35. Pany, M., \& Boy, E. (2019). Prevalensi Nyeri pada Lansia. Magna Medika. Vol. 6, No.2 (pp. 138-145).

DOI: 10.26714/magnamed.6.2.2019.138145 